\title{
FIRST RECORD OF EPIGONUS CONSTANCIAE (GIGLIOLI, 1880), (DEEPWATER CARDINALFISH) (OSTEICHTHYES: EPIGONIDAE), FROM AEGEAN SEA, TURKEY
}

\author{
Okan ÖZAYDIN*, Semih LEBLEBİCI, Efe ULUTÜRK, and Halit FILIZZ
}

Department of Hydrobiology, Faculty of Fisheries, Ege University, Bornova-İzmir, Turkey

Özaydın O., Leblebici S., Ulutürk E., Filiz H. 2007. First record of Epigonus constanciae (Giglioli, 1880), (deepwater cardinalfish) (Osteichthyes: Epigonidae), from Aegean Sea, Turkey. Acta Ichthyol. Piscat. 37 (2): 91-94.

Abstract. Five specimens of Epigonus constanciae (Giglioli, 1880) (deepwater cardinalfish) were captured first time during a bottom trawl survey in Sigacik Bay and off Karaburun, Aegean Sea. This is the first record of the species from the Aegean Sea. A short description certain of morphometric and meristic features of specimens are given.

Keywords: first record, Epigonus constanciae, deepwater cardinalfish, Aegean Sea

The family Epigonidae includes bathydemersal fishes distributed in the all oceans, there are 26 valid species in genus Epigonus (cf. Froese and Pauly 2007). A total of three species of the this family have been known from the Mediterranean Sea, namely Epigonus constanciae (Giglioli, 1880); E. denticulatus Dieuzeide, 1950; E. telescopus (Risso, 1810). E. constanciae has often been reported from the western part of the Mediterranean Sea, except the Ionian Sea, from the eastern Atlantic, off western Africa, off Madeira, and off the Azores and the Canaries (Tortonese 1986, Abramov 1992, De Ranieri and Sbrana 1992, Biagi et al. 2002, D’Onghia et al. 2004, Mytilineou et al. 2005). It chiefly inhabits the upper part of the continental slope. In the eastern tropical Atlantic, E. constanciae can be found within the depth range of 200-600 m eastern tropical Atlantic (Maugé and Mayer 1990) while, in the eastern Ionian Sea this species occurs from 351 to $742 \mathrm{~m}$ (Mytilineou et al. 2005). The adults are strongly associated with the substrate (Tortonese 1986). In this paper we present data on the first record and a re-description of Epigonus constanciae from the Aegean Sea.

During bottom trawling cruises, carried out by F/V IBO REIS, off Karaburun in July 2006 and F/V HAPULOGL at Sigacik Bay in August 2006, a total of 5 specimens of E. constanciae were collected (Tables 1,2). The specimens were fixed and stored in 5-\% formaldehyde solution. The species identification was aided by guidelines provided by Tortonese (1986). The specimens are deposited in the Museum of the Faculty of Fisheries, Ege University, with catalogue numbers ESFM-PIS/2006-1 (off Karaburun) and ESFM-PIS/2006-2 (Sigacik Bay). Morphometric charac- ters were measured to the nearest $0.01 \mathrm{~mm}$ by a digital caliper, specimens were weighed the nearest $0.01 \mathrm{~g}$ digital scales, and meristic characters were counted under the reflected light of a stereomicroscope. No meristic and morphological data, on the species under scrutiny, from the Mediterranean Sea, are available in the relevant literature.

The survey was carried out in the eastern part of the Aegean Sea, the area also affected by industrial trawling fisheries both Greek and Turkish fleets (Fig. 1). Both sampling sites were characterised by muddy bottom and sampling depth were between 275-450 m (off Karaburun) and 150-473 m (Sigacik Bay). Four specimens were collected off Karaburun (towing begun at: lat $38^{\circ} 49^{\prime} \mathrm{N}$, long $26^{\circ} 21^{\prime} \mathrm{E}$ and ended at: lat $38^{\circ} 50^{\prime} \mathrm{N}$, long $26^{\circ} 12^{\prime} \mathrm{E}$ ); and 1 specimen from Sigacik Bay (towing begun at: lat $38^{\circ} 08^{\prime} \mathrm{N}$, long $26^{\circ} 42^{\prime} \mathrm{E}$ and ended at: lat $37^{\circ} 55^{\prime} \mathrm{N}$, long $\left.26^{\circ} 44^{\prime} \mathrm{E}\right)$. The gear used was a of commercial bottom trawl net (44-mm mesh size) and the fish were found in the codend.

All morphometric measurements, meristic counts, and pictures of the specimens are given in the Tables 1 and 2 and Fig. 2. Diagnostic characters were as follows: first dorsal finrays VII, second dorsal finrays I +8 , anal finrays II +8 , pelvic finrays I-5, pectoral finrays 16-18, lateral line scales are large, ctenoid and varied between 46-49. Epigonus constanciae is clearly distinguishes from the other two Mediterranean epigonids by an ossified spine on the operculum (Fig. 2). Gill rakers on first arch have the common styloid shape. Mouth large, lower jaw equal to or projecting slightly beyond upper jaw. The specimens studied were greenish-brown and the fins were partly white in color, dorsal fin membrane dark.

\footnotetext{
* Correspondence: Dr Okan Özaydın, Ege Universitesi, Su Ürünleri Fakültesi, Temel Bilimler Bölümü, 35100, İzmir-Turkey, phone: +902323884000/1942, fax: +902323883685, e-mail: okan.ozaydin@ege.edu.tr
} 
Table 1

Morphometric data for specimens of Epigonus constanciae caught in Aegean Sea

\begin{tabular}{|c|c|c|c|c|c|c|}
\hline \multirow{2}{*}{$\begin{array}{l}\text { Morphometric characters } \\
{[\mathrm{cm}]}\end{array}$} & \multicolumn{4}{|c|}{ Off Karaburun } & \multirow{2}{*}{$\frac{\text { Sigacik Bay }}{5}$} & \multirow{2}{*}{$\begin{array}{c}\text { Relative value } \\
\text { [\% of standard length] }\end{array}$} \\
\hline & 1 & 2 & 3 & 4 & & \\
\hline Total length & 10.76 & 11.47 & 10.83 & 8.75 & 12.20 & - \\
\hline Standard length & 8.89 & 9.31 & 8.80 & 7.16 & 9.98 & - \\
\hline Fork length & 10.76 & 10.39 & 9.37 & 7.71 & 10.33 & - \\
\hline Body weight [g] & 11.67 & 15.86 & 12.50 & 6.47 & 18.94 & - \\
\hline Preopercular length & 3.41 & 3.42 & 3.28 & 2.77 & 3.66 & 37.47 \\
\hline Preorbital length & 0.60 & 0.73 & 0.63 & 0.52 & 0.63 & 7.04 \\
\hline Eye diameter & 1.58 & 1.53 & 1.53 & 1.19 & 1.70 & 17.05 \\
\hline Interorbital distance & 0.90 & 0.97 & 0.85 & 0.69 & 1.01 & 10.00 \\
\hline Prepectoral length & 3.00 & 3.14 & 3.01 & 2.52 & 3.60 & 34.59 \\
\hline Pectoral fin length & 1.62 & 2.02 & 2.02 & 1.43 & 2.28 & 21.22 \\
\hline Prepelvic length & 3.20 & 2.01 & 3.33 & 2.50 & 3.83 & 33.69 \\
\hline Pelvic fin length & 0.52 & 0.53 & 0.56 & 0.36 & 0.63 & 5.86 \\
\hline Pelvic fin height & 1.49 & 1.95 & 1.82 & 1.30 & 2.00 & 19.39 \\
\hline Body depth & 1.97 & 2.16 & 1.95 & 1.50 & 2.29 & 22.38 \\
\hline Predorsal 1 length & 3.43 & 3.53 & 3.32 & 2.58 & 3.54 & 37.13 \\
\hline Dorsal fin 1 length & 1.33 & 1.21 & 0.99 & 0.83 & 1.38 & 13.00 \\
\hline Dorsal fin 1 height & 1.30 & 1.53 & 1.20 & 1.03 & 1.52 & 14.91 \\
\hline Dorsal fin 2 length & 0.98 & 0.99 & 0.92 & 0.84 & 1.00 & 10.71 \\
\hline Dorsal fin 2 height & 1.29 & 1.47 & 1.58 & 1.18 & 1.48 & 15.83 \\
\hline Preanal length & 5.57 & 5.94 & 5.96 & 4.63 & 6.00 & 63.66 \\
\hline Anal fin length & 0.86 & 0.95 & 0.86 & 0.76 & 1.22 & 10.54 \\
\hline Anal fin height & 1.31 & 1.60 & 1.20 & 1.09 & 2.00 & 16.31 \\
\hline Peduncal depth & 0.95 & 0.98 & 0.95 & 0.77 & 1.05 & 10.65 \\
\hline Max. mouth height & 1.03 & 1.18 & 1.04 & 0.89 & 1.11 & 11.90 \\
\hline Max. mouth width & 0.75 & 0.77 & 0.74 & 0.70 & 0.83 & 8.59 \\
\hline
\end{tabular}

Meristic data for specimens of Epigonus constanciae caught in Aegean Sea

Table 2

\begin{tabular}{|c|c|c|c|c|c|}
\hline \multirow{2}{*}{ Meristic characters } & \multicolumn{4}{|c|}{ Off Karaburun } & \multirow{2}{*}{$\frac{\text { Sigacik Bay }}{5}$} \\
\hline & 1 & 2 & 3 & 4 & \\
\hline Pectoral fin ray & 17 & 16 & 16 & 16 & 18 \\
\hline Pelvic fin ray & $\mathrm{I}-5$ & $\mathrm{I}-5$ & I-5 & $\mathrm{I}-5$ & $\mathrm{I}-5$ \\
\hline Dorsal fin 1 ray & VII & VII & VII & VII & VII \\
\hline Dorsal fin 2 ray & $\mathrm{I}-8$ & $\mathrm{I}-8$ & $\mathrm{I}-8$ & $\mathrm{I}-8$ & $\mathrm{I}-8$ \\
\hline Anal fin ray & II-8 & II-8 & II-8 & II-8 & II-8 \\
\hline Caudal fin ray & 26 & 26 & 26 & 26 & 26 \\
\hline Lateral line scales & 48 & 49 & 48 & 46 & 46 \\
\hline
\end{tabular}




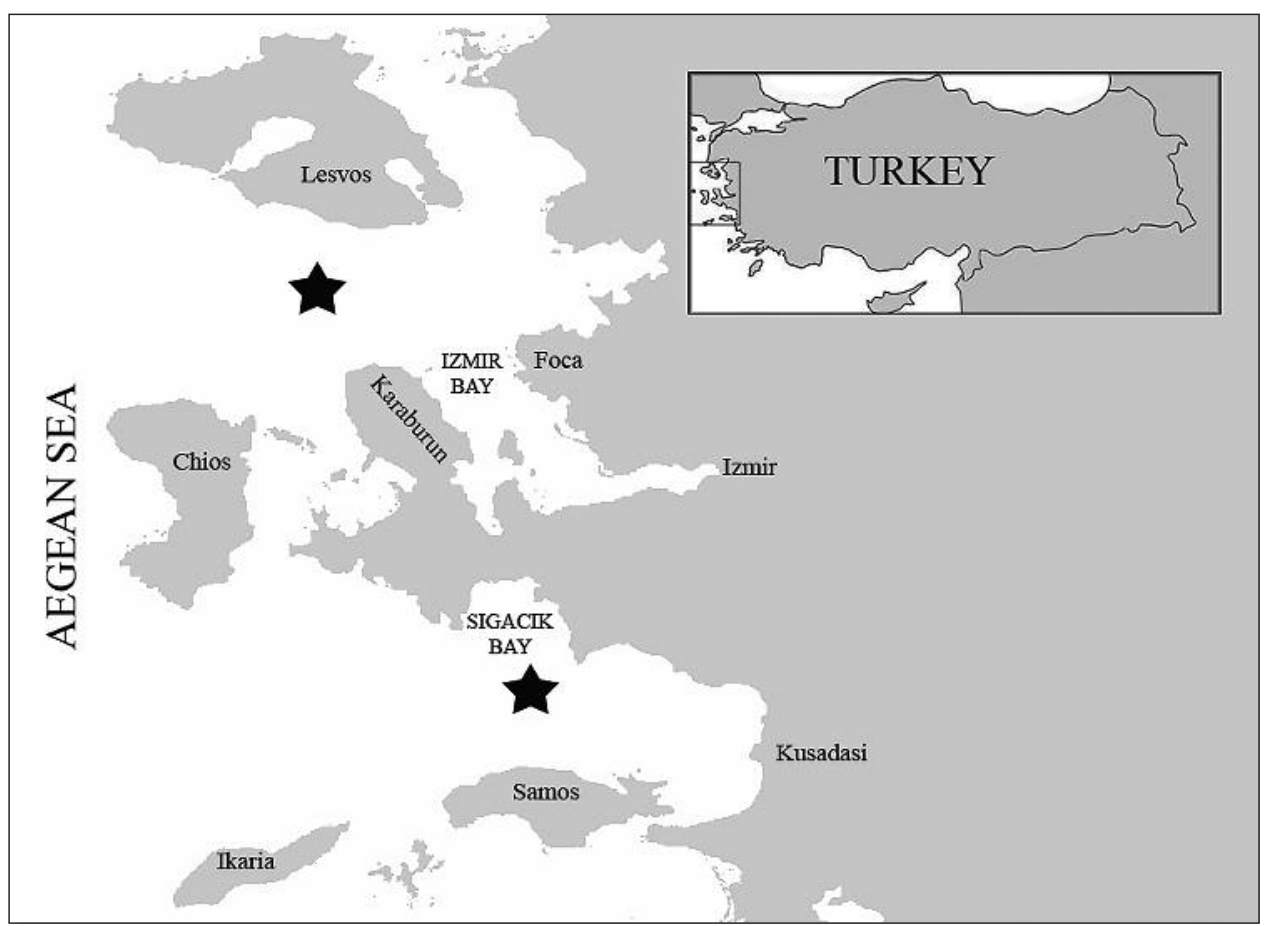

Fig. 1. Map of the sampling area; asterisks show the locality of captured Epigonus constanciae specimens in the central Aegean Sea

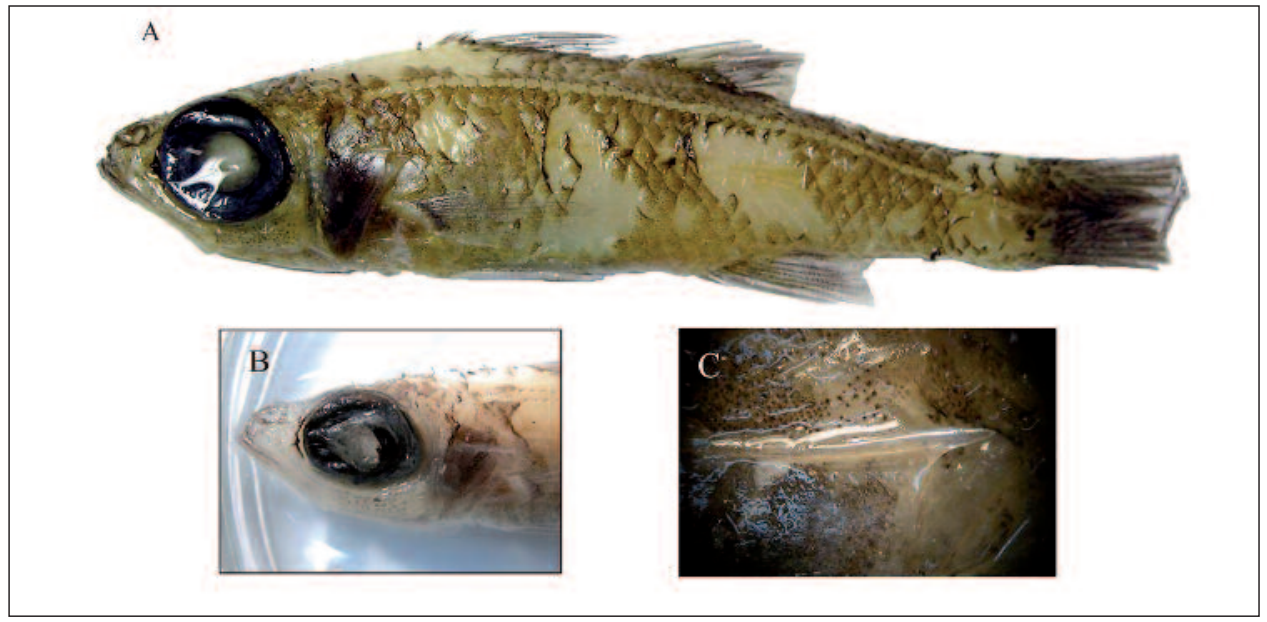

Fig. 2. Epigonus constanciae captured from Aegean Sea; A general view B head view, C operculum spine

\section{ACKNOWLEDGEMENTS}

We would like to thank Dr Sencer Akalin from Ege University for taking photographs and Dr Miltiadis-Spyridon Kitsos from Aristotle University of Thessaloniki for English text revisions and also crew of F/V IBO REIS and F/V HAPULOGLU for obtaining specimens.

\section{REFERENCES}

Abramov A.A. 1992. Species composition and distribution of Epigonus (Epigonidae) in the world ocean. Journal of Ichthyology 32 (5): 94-108.
Biagi F., Sartor P., Ardizzone G.D, Belcari P., Belluscio A., Serena F. 2002. Analysis of demersal assemblages off the tuscany and Latium coasts (North-western Mediterranean). Scientia Marina 66 (Suppl. 2): 233-242.

De Ranieri S., Sbrana M. 1992. Présence de Bellottia apoda (Bythitidae) et de Epigonus constanciae (Apogonidae) dans la mer Tyrrhénienne septentrionale. Cybium 16: 177-180.

D’Onghia G., Politou C.-Y., Bozzano A., Lloris D., Rotllant G., Sion L., Mastrototaro F. 2004. Deep-water fish assemblages in the Mediterranean Sea. Scientia Marina 68 (Suppl. 3): 87-99. 
Froese R., Pauly D. (eds.) 2007. FishBase. World Wide Web elec- Tortonese E. 1986. Apogonidae. Pp. 803-809. In: Whitehead P.J.P. tronic publication. www.fishbase.org version (05/2007).

Maugé L.A., Mayer G.F. 1990. Apogonidae. Pp. 714-718. In: Quero J.C., Hureau J.-C., Karrer C., Post A., Saldanha L. (eds.) Check-list of the fishes of the eastern tropical Atlantic (CLOFEBauchot M.-L., Hureau J.-C., Nielsen J., Tortonese E. (eds.) Fishes of the north-eastern Atlantic and the Mediterranean. Vol. 2. UNESCO, Paris.

TA). Vol. 2. JNICT, Lisbon; SEI, Paris; UNESCO, Paris.

Mytilineou C., Politou C.-Y., Papaconstantinou C., Kavadas S., D'Onghia G., Sion L. 2005. Deep-water fish fauna in the Eastern Ionian Sea. Belgian Journal of Zoology 135: 229-233.

Received: 10 July 2007

Accepted: 16 August 2007

Published electronically: 30 November 2007 